\title{
DAMPAK PENDIRIAN PT. BUMI MENTARI KARYA PADA PENDAPATAN USAHATANI KELAPA SAWIT MASYARAKAT DI DESA TUNGGANG KECAMATAN PONDOK SUGUH KABUPATEN MUKOMUKO
}

\author{
(IMPACT OF ESTABLISHMENT OF PT. BUMI MENTARI KARYA ON \\ PALM OIL FARMING INCOME IN TUNGGANG VILLAGE, \\ SUBDISTRICT OF PONDOK SUGUH, MUKOMUKO REGENCY)
}

\author{
Een Supriadi, Musriyadi Nabiu, Septri Widiono \\ Jurusan Sosial Ekonomi Pertanian Fakultas Pertanian, Universitas Bengkulu
}

\begin{abstract}
The research was conducted in two places; in Tunggang village and Padang Gading Village subdistrict of Sungai Rumbai, Mukomuko District, Bengkulu Province on February 5 to March 5, 2011. These research areas were selected purposively. Tunggang village is just exactly the same as the plant location of PT Bumi Mentari Katya while Padang Gading Village, as comparison village. The objective of this research is to examine the impact of establishment of PT Bumi mentari Karya on farming income in the communities around the oil palm plant. In this study, the palm oil farmers which are being sampled are 69 people. On regard with it, this study only performs with and without analysis; the initial state of the palm oil farmers (before the company) is described qualitatively which is Padang Gading Village as the comparison village and the state of palm oil farmers after the company is established. Income farming Crude plam more the after PT. Bumi Mentari karya means were statistically difference These results indicate presence of the oil palm industry PT. Bumi Mentari Karya Giving a positive impact on farm income of oil palm Tunggang Village.
\end{abstract}

Keywords: income, palm planters

\section{PENDAHULUAN}

Pengembangan Agribisnis kelapa sawit merupakan salah satu langkah yang diperlukan sebagai kegiatan pembangunan subsektor perkebunan dalam rangka revitalisasi sector pertanian. Perkembangan pada berbagai subsistem yang sangat pesat pada agribisnis kelapa sawit menjelang akhir tahun 1970an menjadi bukti pesatnya perkembangan agribisnis kelapa sawit (Riska 1994 dalam 
Permatasari, 2008). Pengembangan perkebunan rakyat diyakini tidak saja meningkatkan kesejahteraan rakyat, bahkan dapat meningkatkan devisa negara,penyerapan tenaga kerja baik industri hulu yaitu perkebunan itu sendiri maupun industri hilir. Komoditi kelapa sawit berbeda dengan komoditi perkebunan lain karena memerlukan pabrik yang dekat dengan petani, agar buah yang dihasilkan petani dapat segera dikirim ke pabrik (dalam waktu $<24$ jam) supaya kualitas minyak tidak mengandung asam lemak yang tinggi (Mubyarto dan dkk 1989 dalam Permatasari, 2008).

Awalnya, perkebunan kelapa sawit di Indonesia hanya dilaksanakan oleh perkebunan besar negara dan perkebunan swasta. Menyadari peran kelapa sawit yang pontensial dalam perolehan devisa, maka pemerintah merintis pengembangan model pembangunan perkebunan rakyat. Dalam pengembangannya diintegrasikan dengan Perkebunan Besar Swasta Nasional (PBSN) maupun Perkebunan Besar Nasional (PBN) . Program ini mulai dilaksanakan pada tahun 1977 dengan dicanangkannya Perusahaan Inti Rakyat (PIR) Yang terdiri PIR Lokal dan PIR khusus ( Direktorat Jendral Perkebunan 1992 Dalam Helvina 2011). Pengembangan perkebunan rakyat secara cepat ini merupakan salah satu tujuan pemerintah,karena disamping memperoleh devisa negara juga memperluas kesempatan kerja dan sekaligus juga meningkatkan kesejahtraan rakyat . Kelapa sawit di Indonesia merupakan komoditas primadona luasnya terus berkembang dan tidak hanya menjadi monopoli perkebunan besar negara atau perkebunan besar swasta. Saat ini perkebunan rakyat sudah berkembang dengan pesat (Rahman dan Subroto.2002).

Pola perkebunan inti rakyat merupakan variasi lain dari pola sentralisasi. Pihak investor dalam pola PIR biasanya memiliki dan mengelola perkebunan sebagaimana dilakukan oleh petani. Perkebunan yang dikelola biasanya berdekatan dengan pabrik yang mengolah komoditas perkebunan tersebut. Perkebunan yang dikelola biasanya cukup luas sehingga mampu memberikan jaminan atas pasokan bahan baku bagi pabrik yang didirikan, bisa juga perkebunan yang ada kurang besar sehingga memerlukan pasokan dari luar perkebunan yang dimiliki. Perkebunan yang secara langsung dikelola biasanya dijadikan sebagai jaminan bagi pabrik pengolah.

Berdirinya perusahaan-perusahaan di suatu daerah tertentu akan berpengaruh secara makro terhadap kondisi perekonomian nasional serta memiliki dampak terhadap kondisi ekonomi masyarakat di sekitar perusahaan itu didirikan (Helvina, 2011).

Sehubungan dengan uraian diatas, berdirinya PT Bumi Mentari Karya di Desa Tunggang adalah sebagai salah satu perusahaan perkebunan kelapa sawit swasta yang mengandalkan hasil perkebunan masyarakat untuk pasokan produksi tentu memiliki pengaruh terhadap pendapatan masyarakat disekitar Lokasi perkebunan. Produksi Tandan Buah Segar yang diolah oleh PT Bumi Mentari Karya Hanya mengandalkan perkebunan masyarakat tanpa ada pasokan produksi dari perkebunan sendiri karena PT Bumi Mentari Karya hanya memiliki pabrik dan tidak ada perkebunan sendiri. 
Dari latar belakang yang telah diuraikan, maka pertanyaannya adalah apakah keberadaan perusahaan memberi dampak positif terhadap masyarakat?. Oleh sebab itu, tujuan penelitian ini adalah untuk mengetahui seberapa besar perusahaan memberi dampak positif terhadap pendapatan usahatani kelapa sawit masyarakat.

\section{METODOLOGI PENELITIAN}

Sesuai dengan tujuan penelitian untuk mengetahui dampak pendapatan usahatani petani kelapa sawit sekitar PT Bumi Mentari Karya maka lokasi penelitian ini ditentukan secara sengaja (purposive) yaitu di Desa Tunggang Kecamatan Pondok Suguh, Kabupaten Mukomuko, Propinsi Bengkulu, yang lokasi wilayah desa ini berada dilokasi perusahaan dan memiliki mitra dengan perusahaan dan Desa Padang Gading, Kecamatan Sungai Rumbai desa nonmitra sebagai gambaran pendapatan usahatani kelapa sawit sebelum bermitra dengan perusahaan. Lokasi Desa Padang Gading berada $14 \mathrm{Km}$ dari perusahaan dengan keadaan jalan yang masih kurang baik dengan jalan kebun yang belum memadai. Luas lahan kadua Lokasi penelitian yaini Desa Tunggang Dan Desa Padang Gading Relatif Homogen dengan rata -rata \pm 3 Ha. Dengan pertimbangan uraian diatas peneliti memutuskan memilih lokasi penelitian pada kedua desa tersebut yaini Desa Tunggang Dan Desa Padang Gading.

\section{Metode Pengambilan Responden}

Penentuan responden dilakukan dengan metode Simple Random Sampling yaitu pengambilan responden secara acak, dimana tiap unit populasi memiliki peluang / ke sempatan yang sama untuk dipilih menjadi responden (Nazir, 1988).

Dalam penelitian ini petani kelapa sawit yang menjadi responden adalah petani yang berada disekitar Desa Tunggang sejumlah 148 orang dan Desa Padang Gading jumlah petaninya adalah sebanyak 85 orang. Jumlah total kedua desa 233 petani kelapa sawit. Dengan menggunakan bound of error (B) berdasar selisih rata-rata total luas lahan populasi yang pada masing-masing Desa yang akan dijadikan responden. Di Desa Tunggang rata -rata luas lahan 3,32 Ha untuk Desa Padang Gading rata-rata luas lahan 3,06 Ha maka jumlah responden yang diperoleh dari kedua populasi tersebut seperti ditunjukkan sebagai berikut:

$$
n=\frac{(N) \sigma^{2}}{(N-1) D+\sigma^{2}} \quad(\text { Nazir, 1988) }
$$

dimana : o2 :Varian Populasi, N : Besarnya populasi, D: Konstanta, dimana $\mathrm{D}=\mathrm{B}^{2} / 4\left(0,26^{2} / 4=0.017\right)$, B: Bound of Error $(0,26)$, $\sigma^{2}$ : Varian populasi 
$(1,69)$. Dengan : N : 233 petani kelapa sawit, $\delta^{2}: 1.69, B^{2}: 0,26^{2} / 4, D \quad: \quad B^{2} / 4$ $=(0.017)$, maka

$$
\begin{aligned}
& n=\frac{233(1,69)}{(232) 0.017+1,69} \\
& n=68,69 \approx 69 \text { Petani }
\end{aligned}
$$

Sementara itu, jumlah responden yang diambil untuk masing-masing desa ditentukan berdasarkan proporsi. Jumlah responden (n) dihitung dengan rumus sebagai berikut :

a) Desa Tunggang Sebanyak :

Nss

$$
\begin{aligned}
& =\mathrm{n} \times \text { Wss } \\
& =69 \times 0,6351 \\
& =43,8219 \approx 44 \text { petani }
\end{aligned}
$$

b) Desa Padang Gading sebanyak:

Nrs $\quad=\mathrm{n} \times \mathrm{Wss}$

$=69 \times 0,3648$

$=25,1712 \approx 25$ petani

dimana $\mathrm{n}$ adalah Jumlah responden, $\mathrm{N}$ adalah Besarnya populasi, Nss adalah Jumlah Petani di Desa Tunggang, Nrs adalah Jumlah petani di Desa Padang gading, Wss adalah Proporsi petani di desa Tunggang, Wrs adalah Proporsi petani di desa Padang Gading

\section{Metode Pengumpulan Data}

Data yang dikumpulkan dalam penelitian ini adalah meliputi data primer dan data sekunder. Data primer diperoleh melalui observasi dan melalui wawancara langsung dengan responden menggunakan daftar pertanyaan (kuisioner) yang telah dipersiapkan terlebih dahulu. Data sekunder diperoleh dari literatur-literatur atau pustaka dan instansi-instansi atau lembaga-lembaga yang terkait dengan penelitian ini.

\section{Metode Analisa Data}

\section{Analisis Pendapatan Usahatani Kelapa Sawit}

Analisis data yang digunakan untuk mengetahui perubahan pendapatan usahatani kelapa sawit dengan Keberadaan industri kelapa sawit PT. Bumi Mentari Karya apakah Memberi dampak positif bagi pendapatan usahatani kelapa sawit di Desa Tunggang. Untuk melihat dampak pembangunan industri kelapa sawit terhadap pendapatan bagi masyarakat sekitar dapat dilakukan dengan dua pendekatan yakni sebelum dan sesudah (pre_post) dan pendekatan tanpa dan dengan ( with and without). Secara umum, pendapatan diperhitungkan sebagai penerimaan dikurangi dengan semua biaya telah dikeluarkan.secara matematis pendapatan dapat dituliskan sebagai berikut, (Soekartawi,1999). Rumus yang digunakan yaitu :

$$
\begin{aligned}
& \mathrm{Pd}=\mathrm{TR}-\mathrm{TC} \\
& \mathrm{TR}=\mathrm{Y}-\mathrm{Py}
\end{aligned}
$$




$$
\begin{aligned}
& \mathrm{TC}=\mathrm{FC}+\mathrm{VC} \\
& \mathrm{VC}=\mathrm{Px} . \mathrm{X}
\end{aligned}
$$

dimana : TR= Total Penerimaan petani $(\mathrm{Rp}), \mathrm{TC}=$ Biaya Total yang dikeluarkan oleh petani(Rp), $\mathrm{Y}=$ Produksi Usaha $(\mathrm{Kg})$, Py = Harga Produk yang dihasilkan $(\mathrm{Rp} / \mathrm{Kg}), \quad \mathrm{FC}=$ Biaya Tetap $(\mathrm{Rp}), \mathrm{VC}=$ Biaya Variable $(\mathrm{Rp}), \quad \mathrm{Px}=$ Harga Input $(\mathrm{Rp}), \quad \mathrm{X}=$ Jumlah Input (Satuan), dan Pd=Pendapatan Usahatani (Rp).

\section{Analisis Uji Beda Rata-rata Pendapatan Usahatani Kelapa Sawit}

Untuk mengetahui apakah ada perbedaan rata-rata pendapatan usahatani kelapa sawit desa Tunggang dengan desa Padang Gading biasa digunakan analisis uji beda nilai tengah $t$ (uji $t$ ) dengan tingkat kepercayaan $95 \%$ adapun rumus thitung menurut (Djarwanto dan Subagyo,1993) :

$$
\mathrm{t}=\frac{\tilde{\mathrm{x}}_{2}-\widetilde{\mathrm{x}}_{1}}{\sqrt{S P^{2}\left(\frac{1}{n_{1}}+\frac{1}{n_{2}}\right)}}
$$

dimana $x_{1}=$ Pendapatan petani kelapa sawit desa Tunggang $(\mathrm{Rp} / \mathrm{Th}), x_{2}=$ Pendapatan petani kelapa sawit desa Padang Gading $(\mathrm{Rp} / \mathrm{Th}), \tilde{x}_{1}=$ Rata-rata pendapatan petani desa Tunggang, $\tilde{x}_{2}=$ Rata-rata pendapatan petani desa Padang Gading, $S_{1}{ }^{2}=$ Keragaman usahatani kelapa sawit desa Tunggang, $S_{2}{ }^{2}=$ Keragaman usahatani kelapa sawit desa Padang Gading, $S P^{2}=$ Keragaman sampel, $n_{1}=$ Jumlah responden petani Desa Tunggang, $n_{2}=$ Jumlah responden petani desa Padang Gading

\section{HASIL DAN PEMBAHASAN}

\section{Karakteristik Responden Petani Kelapa Sawit}

Karakteristik petani berguna untuk mengetahui keadaan sebenarnya dari petani yang di jadikan responden dalam penelitian. Responden Di Desa Tunggang berjumlah 44 orang dan responden di Desa Padang Gading Berjumlah 25 orang. Responden di Desa Padang Gading Rata - rata berusia produktif, karena menurut Mubyarto (1989) usia produktif berkisar antara 15-64 tahun dilihat umur responden di Desa Tunggang Berkisar antara 25 - 67 tahun. Kondisi yang sama terjadi di Desa Padang Gading dimana usia reponden didaerah Padang Gading juga berusia pada kategori produktif.

Pendidikan adalah salah satu faktor penunjang keberhasilan petani dalam melaksanakan usahataninya, karena tingkat pendidikan sangat mempengaruhi kemampuan petani dalam bertindak dan cara pengambilan keputusan, seperti menyerap suatu inovasi dalam mengelola usahataninya (Doni, 2008). Rata-rata tingkat pendidikan yang pernah ditempuh oleh petani kelapa sawit di Desa Tunggang relatif rendah. Persentase tingkat pendidikan terbesar berada pada tingkat pendidikan ( $<7$ tahun) yaitu sebesar 56,82\%. Hal ini menunjukkan 
tingkat pendidikan petani masih berada pada tingkat Sekolah Dasar (SD). Di Desa Padang Gading, 76,00 \% memiliki lama pendidakan kurang dari 7 tahun atau setingkat dengan Sekolah Dasar (SD). Pendapat Soekartawi (1999) yang menyatakan pendidikan yang rendah menjadi kendala dalam proses adopsi inovasi teknologi dan sebaliknya pendidikan yang tinggi berpengaruh terhadap cepatnya tingkat adopsi inovasi yang diterima oleh petani.

Pendidikan nonformal yang didapat petani seperti pelatihan mengenai usaha pertanian yang dijalankannya juga mempengaruhi usaha pertanian mereka. Dalam melakukan pengembangan dimulai dari cara budidaya, pemakaian teknologi tepat guna cara pemberian pupuk dan cara mempertahankan kualitas produk dan membantu mereka mengakses teknologi yang berkaitan dengan usaha pertanian mereka. Hasil penelitian dilapangan menunjukkan bahwa pada Desa Tunggang rata-rata penduduk yang pernah mengikuti pelatihan resmi diadakan menyatakan pernah satu kali mengikuti penyuluhan sebanyak $20,00 \%$ dan sebanyak $20,45 \%$ pernah mengikuti dua kali penyuluhan. $59.55 \%$ menyatakan tidak pernah mengikuti penyuluhan namun mengetahui tahu cara pola budidaya dari informasi mulut kemulut.

Jumlah anggota keluarga mengambarkan jumlah orang yang menjadi tanggungan kepala keluarga responden. Jumlah anggota keluarga terbanyak di Desa Tunggang adalah 3-4 orang yakni sebesar 68,18\%. Sementara di Desa Padang Gading jumlah tanggunggan 3-4 orang sebesar 64,00 \%. Jumlah anggota keluarga akan berpengaruh dalam suatu usahatani hal ini sejalan menurut hasil penelitian Nahriyanti (2008) jumlah anggota keluarga petani akan berpengaruh bagi petani dalam perencanaan dan pengambilan keputusan petani dalam hasil usahataninya, karena anggota keluarga petani dapat merupakan sumber tenaga kerja dalam kegiatan usahatani terutama anggota keluarga yang produktif.

Pengalaman petani dalam berusahatani kelapa sawit akan berpengaruh pada cara ketelatenan perawatan, peningkatan hasil atau cara panen yang baik. Hasil penelitian menemukan bahwa petani di Desa Tunggang yang memiliki pengalaman usaha antara 6-10 tahun sebesar 52,27 \% sementara di Desa Padang Gading sebesar $71,43 \%$. Hasil ini juga menginformasikan bahwa usia perkebunan rakyat pada desa ini dalam usia yang produktif untuk menghasilkan. Dengan kata lain penelitian pada Desa Tunggang dan Padang Gading menunjukkan bahwa usaha perkebunan mereka masih bisa ditingkatkan tingkat produktifitasnya dalam tahun-tahun mendatang mengingat usia perkebunan pada kedua desa sekarang masih masa produktif.

Sebagian besar penduduk Desa Tunggang dan Desa Padang Gading memiliki pekerjaan sampingan. Pekerjaan sampingan ini memberikan kontribusi penghasilan keluarga petani tiap bulannya. Pada penduduk Desa Tunggang mata pencarian yang berpendapatan tetap seperti buruh pabrik dan karyawan pabrik sebesar 20,45 \% dan buruh berpendapatan tidak tetap sebesar $20 \%$. Di desa Tunggang dan Padang Gading, masyarakat bertani tanaman pangan dan sejenisnya yang diusahakan secara subsisten dan berusahatani kelapa sawit. 


\section{Produktivitas Usahatani Kelapa Sawit}

Pengembangan kebun kelapa sawit rakyat di Desa Tunggang relatif sama dengan Desa Padang Gading yakni sekitar 11-12 tahun lalu. Kini kondisi kedua desa tersebut relatif berbeda dilihat dari aspek ekonominya Pada Desa Tunggang Sistem usahatani kelapa sawit dikembangkan sekitar 12 tahun lalu. Sedangkan keberadaan perusahaan PT.Bumi Mentari Karya mulai beroperasi pada tahun 2006.

Tabel 1. Produktivitas Usahatani Kelapa Sawit Desa Tunggang Dan Padang Gading (2011)

\begin{tabular}{lcc}
\hline \multirow{2}{*}{ Uraian } & \multicolumn{2}{c}{ Produktivitas } \\
\cline { 2 - 3 } & Tunggang $(\mathrm{n}=44)$ & Padang Gading(n=25) \\
\hline Produksi $(\mathrm{Kg})$ & $87.185,00$ & $57.265,60$ \\
Produksi $(\mathrm{Kg} / \mathrm{Ha})$ & $27.330,72$ & $18.008,05$ \\
Produktivitas(Kg/ha/Bln) & $2.277,56$ & $1.500,67$ \\
\hline
\end{tabular}

Sumber : Data diolah 2011

Tabel 1, menunjukkan bahwa secara keseluruhan produktivitas kebun kelapa sawit petani di Desa Tunggang lebih tinggi setelah memiliki kemitraan dengan perusahaan dengan luas lahan yang relative homogen yaitu \pm 3 ha di peroleh hasil produktivitas usahatani pada Desa Tungggang sebesar $87.185,00(\mathrm{Kg})$ perluas lahan dalam satu tahun atau sebesar $27.330 .72(\mathrm{Kg} / \mathrm{Ha})$ pertahun. Produktivitas rata dalam satu bulan sebesar 2.277,56 Kg/Ha. Desa Padang Gading produktivitas rata-rata usahatani diperoleh hasil sebesar 57.265,60 (Kg) dalam satu tahun atau sebesar 18.008,05 (Kg/Ha). Rata-rata produktivitas perbulan sebesar 1.500,67 (Kg/Ha/Bulan). Beberapa hal penyebab perbedaan produktivitas tanaman kelapa sawit antara lain: Teknologi budidaya kelapa sawit yang meliputi perawatan, peggunaan pupuk dan cara pemupukan.

\section{Pengaruh Teknologi Budidaya dalam Produktivitas Kelapa Sawit}

Produktivitas usahatani kelapa sawit sangat tergantung pada umur tanaman, jarak tanaman, dan penggunaan pupuk, Cara pemupukan. Produksi sawit dimulai pada tahun ke 4 dan terus berproduksi sampai pohon sawit berusia 25-30 tahun (Pahan 2010 dalam Helvina 2011). Puncak produksi per Ha tercapai pada usia 9 sampai 14 tahun,dimana mencapai produksi 20 ton/Ha dan secara perlahan-lahan mengalami penurunan sampai tahun ke 29. 29 tahun (Pardamean.2007). Komponen Teknologi budidaya kelapa sawit Desa Tunggang dan Desa Padang Gading diperoleh hasil penelitian sebagai berikut. 
Tabel 2. Pemakaian Teknologi Budidaya Desa Tunggang dan Desa Padang Gading (2011)

\begin{tabular}{lcc}
\hline \multirow{2}{*}{ Uraian } & \multicolumn{2}{c}{ Jumlah Rata rata } \\
\cline { 2 - 3 } & Tunggang & Padang Gading \\
\hline Umur tanaman (Th) & 12,20 & 11.00 \\
Jarak tanam (M/Ha) & 9,00 & 8,00 \\
Jumlah tanaman (Per & 121,20 & 135,32 \\
Ha) & & - \\
Dosis Pupuk & 886.36 & - \\
Urea (Kg/Ut/Th) & 809.09 & - \\
KCL (Kg/Ut/Th) & 831.82 & 552.00 \\
TSP (Kg/Ut/Th) & & 584.00 \\
Sp-36 (Kg/Ut/Th) & & \\
Poska (Kg/Ut/Th) & &
\end{tabular}

Sumber : Data diolah 2011

Hasil penelitian diperoleh hasil rata-rata umur tanaman sebesar 12,20(Th) pada Desa Padang Gading dan sebesar 11,00 (Th) dengan demikian umur usahatani kelapa sawit pada Desa Tunggang dan Padang Gading sama-sama memasuki usia produktif. Menurut Pahan (2010) menyatakan jumlah tanaman yang baik dalam satu hektar adalah antara 120 hingga 136 batang dalam satu hektar. Penanaman Bibit kelapa sawit dilaksanakan dilapangan dengan jarak tanan $9 \times 9 \times 9 \mathrm{~m}$ dengan sistem segitiga sama sisi .

Penanaman bibit dilakukan pada lubang tanam ukuran $40 \times 40 \times 40 \mathrm{~cm}$ dan dalamnya penanaman tepat diatas leher akar sedikit diatas permukaan tanah. Penanaman yang terlalu dalam dan jarak tidak tepat, selain menyebab tidak berbuah juga mengganggu titik tumbuh. Hasil penelitian diperoleh jarak tanam yang tabel 12, menunjukkan rata-rata jarak tanam pada Desa Tunggang 9.00 (M/Ha) dan pada Desa Padang Gading 8,00 (M/Ha) dengan jumlah tanaman sebanyak 121,20 batang (Ha) Pada Desa Tunggang dan pada Desa Padang Gading sebanyak 135,32 batang (Ha). Hadi 2001 dalam Togatorop (2005) mengatakan bahwa pada umumnya tanaman kelapa sawit yang tumbuh di Indonesia secara global pemupukan yang baik dilakukan 2-3 kali dalam setahun pada tanaman yang telah menghasilkan umur 4 tahun dengan dosis pupuk 2-4 $\mathrm{kg} /$ batang. Dosis pupuk di rekomendasikan perusahaan PT. Bumi Mentari Karya jenis pupuk yang baik bagi tanaman kelapa sawit dengan dosis Urea antara 200-300 Kg/Ha, KCL antara 250- 400 $\mathrm{Kg} / \mathrm{Ha}$, TSP Sebesar 250-400 Kg/Ha. Dilihat dari hasil penelitian terdapat perbedaan dosis dan jenis pupuk serta dosis yang dipakai dengan total pemakaian pupuk pada Desa Tunggang lebih besar.

Pengendalian gulma menggunakan pengendalian secara manual dan kimia. Pada pengendalian kimia pada Desa Tunggang dipakai jenis merek pestisida Round-up, Gramaxone, Kleen-up dan Desa Padang Gading jenis yang dipakai round-up. Pengendalian hama tidak memakai jenis merek kimia namun 
hanya ditangani dengan cara manual. Hasil Tabel 3, menunjukkan bahwa keberadaan perusahaan memberi pengaruh mengenai tatacara budidaya tanaman kelapa sawit pada Desa Tunggang mulai dari jenis pupuk yang baik dipakai untuk tanaman kelapa sawit, jumlah dosis yang dipakai dan tata cara pengendalian gulma yang lebih intensif hal ini mempengeruhi terhadap peningkatan hasil produksi tandan buah segar. Menurut Anonymous system budidaya yang baik mulai dari dosis Teknis pemupukan, Dosis pupuk, pengendalian gulma, jarak tanam, cara panen berpengaruh terhadap a). Jumlah Tandan / Pohon/tahun, b). Berat tandan / Pohon, C. Produksi tandan / Ha dan d). Pertumbuhan pohon (Anonymous, 1980 dalam Zakir. 1990)

\section{Pengunaan dan Biaya Produksi Usahatani Kelapa Sawit}

\section{Biaya Tidak Tetap ( Variabel Cost)}

Jenis pupuk yang digunakan oleh petani di Desa Tunggang adalah pupuk Urea dengan rata rata harga $\mathrm{Rp} .1,805,45 \mathrm{Rp} / \mathrm{Kg}$, TSP dengan rata rata harga Rp.2.379,09Rp/Kg, dan KCL dengan rata-rata harga Rp.3.219,55 Rp/Kg. Desa Padang Gading harga pupuk SP36 dengan harga Rp.1.908,00 Rp/Kg dan phoska dengan rata rata harga Rp.2.730,00 Rp/Kg. Rata-rata jumlah penggunaan dan biaya yang dikeluarkan petani untuk pembelian pupuk pada Desa Tunggang dan Desa Padang Gading dapat dilihat pada Tabel 4.

Tabel 3. Rata-Rata Jumlah Penggunaan dan Biaya Pupuk Usahatani kelapa sawit di Desa Tunggang dan Padang Gading.

\begin{tabular}{lrrrr}
\hline \multirow{2}{*}{ Jenis Pupuk } & \multicolumn{2}{c}{ Tunggang } & \multicolumn{2}{c}{ Padang Gading } \\
\cline { 2 - 5 } & $(\mathrm{Rp} / \mathrm{Ut})$ & $(\mathrm{Rp} / \mathrm{Ha})$ & $(\mathrm{Rp} / \mathrm{Ut})$ & $(\mathrm{Rp} / \mathrm{Ha})$ \\
\hline Urea & $1.595 .954,55$ & $500.299,23$ & - & \\
KCL & $2.592 .681,82$ & $812.752,92$ & - & \\
TSP & $2.106 .681,82$ & $660.401,82$ & - & \\
SP36 & - & & $1.057 .800,00$ & $332.641,51$ \\
Phoska & - & & $1.593 .400,00$ & $501.069,18$ \\
\hline Jumlah & $6.295 .318,19$ & $1.973 .453,97$ & $2.651 .200,00$ & $833.710,69$ \\
\hline
\end{tabular}

Sumber : Data diolah pada 2011

\section{Penggunaan dan Biaya Pestisida}

Pemberian pestisida bertujuan untuk membasmi gulma, hama dan penyakit yang menyerang tanaman. Pemberian pestisida harus diberikan secara tepat, baik waktu pemberian, jenis pestisida dan dosisnya sehingga dapat dicapai keberhasilan usahatani dan dapat mengurangi risiko kegagalan panen. Adapun jenis pestisida yang digunakan adalah pada Desa Tunggang adalah merek dagang Round-up dengan rata-rata harga $\mathrm{Rp}$ 42.386/liter,Gramaxsone dengan rata-rata harga Rp. 39.545 / Liter dan Kleen-up dengan rata-rata harga Rp. 27.136 /Liter. Desa Padang Gading memakai Round-up dengan rata-rata 
harga Rp. 46.200 /liter. Rata-rata jumlah penggunaan dan biaya yang dikeluarkan petani untuk pembelian pestisida dapat dilihat pada Tabel 5 .

Tabel 4. Rata-Rata Jumlah Penggunaan dan Biaya Pestisida Usahatani Kelapa Sawit di Desa Tunggang dan Desa Padang Gading.

\begin{tabular}{lcccc}
\hline \multirow{2}{*}{ Jenis Pestisida } & \multicolumn{2}{c}{ Tunggang } & \multicolumn{2}{c}{ Padang Gading } \\
\cline { 2 - 5 } & $(\mathrm{Rp} / \mathrm{Ut})$ & $(\mathrm{Rp} / \mathrm{Ha})$ & $(\mathrm{Rp} / \mathrm{Ut})$ & $(\mathrm{Rp} / \mathrm{Ha})$ \\
\hline Round-up & $354.090,91$ & $111.000,29$ & $552.400,00$ & $173.710,69$ \\
Gramaxone & $253.500,00$ & $79.467,08$ & & \\
Kleen-up & $172.715,91$ & & & \\
\hline Jumlah & $780.306,82$ & $190.467,37$ & $552.400,00$ & $173.710,69$ \\
\hline
\end{tabular}

Sumber : Data diolah pada 2011

Tabel 4, menunjukkan Desa Tunggang lebih banyak dalam pemakaian pestisida dan pengeluaran biaya yang lebih besar dibanding Desa Padang Gading. Jumlah penggunaan pestisa pada Desa Tunggang sebesar 20,09 liter dengan total biaya Rp.780.306,82 untuk setiap usahatani atau $\mathrm{Rp}$ 190.467,37 dalam setiap hektar. Desa Padang Gading total pemakaian pestisida sebesar 11,72 Liter dengan rata-rata biaya Rp. 552.400 setiap usahatani atau sebesar Rp 173.710,69 setiap hektarnya. Tabel 4, menunjukkan bahwa pemakaian dan biaya pestisida lebih banyak dan dengan biaya lebih besar dalam perawatan gulma dan hama penyakit yang ada di perkebunan mereka yang bisa menggangu produktivitas usahatani kelapa sawit masyarakat di di Desa Tunggang.

\section{Penggunaan dan Biaya Tenaga Kerja}

Tenaga kerja merupakan faktor produksi yang sangat penting dalam usahatani, disamping pupuk, pestisida dan alat-alat pertanian. Input tenaga kerja berperan sebagai pengelola atau sebagai penggerak input lainnya untuk menghasilkan produksi. Tenaga kerja yang digunakan dalam usahatani kelapa sawit berasal dari dalam keluarga dan luar keluarga, tenaga kerja yang digunakan mencakup tenaga kerja pria dan wanita. Tenaga kerja pria digunakan mulai dari pemupukan, penyemprotan hama dan penyakit tanaman, penyiangan dan pemangkasan dan pemanenan. Sementara tenaga kerja wanita hanya digunakan pada pemupukan. Rata-rata penggunaan tenaga kerja untuk pemupukan terdiri dari tenaga pria dan wanita baik dari tenaga kerja dalam dan luar keluarga (Tabel 5 dan 6).

Tabel 6, menunjukkan total biaya rata-rata tenaga kerja Desa Tunggang lebih besar dbandingkan Desa Padang Gading. Biaya tenaga kerja di Desa Tunggang Sebesar Rp. 11.660.681,82 perusahatani atau sebesar Rp. 3.655.386,15 per hektar pada Desa Padang Gading sebesar Rp. 8.349.866,67 perusahatani atau sebesar Rp. 2.625.744,24 per hektar. Biaya yang paling besar dikeluarkan adalah biaya pemanenan yaitu dilakukan dua kali dalam sebulan dengan kebutuhan tenaga kerja lebih kurang dua orang dalam satu hektarnya, biaya selanjutnya biaya pupuk, penyemprotan dan penyiangan. 
Tabel 5. Rata-rata jumlah penggunaan tenaga kerja usahatani kelapa sawit Desa Tunggang dan Desa Padang Gading

\begin{tabular}{llrrrr}
\hline \multirow{2}{*}{ No } & \multicolumn{1}{c}{ Uraian } & \multicolumn{2}{c}{ Tunggang } & \multicolumn{2}{c}{ Padang Gading } \\
\cline { 3 - 6 } & \multicolumn{1}{c}{ OK } & HOK & OK & HOK \\
\hline $1 \quad$ Tenaga kerja dalam keluarga & & & & \\
\cline { 2 - 5 } & a. Tenaga kerja Pemupukan pria & 1,00 & 5,07 & 1,00 & 7,18 \\
b. Tenaga kerja pemupukan wanita & 1,00 & 5,07 & 1,00 & 3,96 \\
c. Tenaga kerja penyemprotan & 1,00 & 2,98 & 1,00 & 1,23 \\
d. Tenaga kerja Penyiangan & 1,00 & 2,98 & 1,00 & 0,24 \\
$\quad$ dan pemangkasan & 2,00 & 56,91 & 2,00 & 50,88 \\
e. Tenaga kerja Panen & & & & \\
Tenaga kerja Luar keluarga & 2,00 & 5,07 & 1,00 & 8,12 \\
a. Tenaga kerja Pemupukan pria & 1,00 & 5,07 & 1,00 & 6,06 \\
b. Tenaga kerja pemupukan wanita & 1,00 & 2,98 & 1,00 & 1,43 \\
c. Tenaga kerja penyemprotan & 2,00 & 13,66 & 1,00 & 7,96 \\
d. Tenaga kerja Penyiangan & 4,00 & 140,55 & 3,00 & 78,72 \\
$\quad$ dan pemangkasan & & & & \\
e. Tenaga kerja Panen & &
\end{tabular}

Sumber : Data diolah 2011

Tabel 6. Rata-Rata Jumlah Biaya Tenaga Kerja Dalam dan Luar Keluarga Usahatani Kelapa sawit Pada Desa Tunggang dan Padang Gading

\begin{tabular}{lcccc}
\hline \multirow{2}{*}{ Uraian } & \multicolumn{2}{c}{ Tunggang } & \multicolumn{2}{c}{ Padang Gading } \\
\cline { 2 - 5 } & $(\mathrm{Rp} / \mathrm{Ut})$ & $(\mathrm{Rp} / \mathrm{Ha})$ & $(\mathrm{Rp} / \mathrm{Ut})$ & $(\mathrm{Rp} / \mathrm{Ha})$ \\
\hline TK Dalam Keluarga & $3.439 .431,82$ & $1.078 .191,79$ & $3.398 .133,33$ & $1.068 .595,39$ \\
TK Luar Keluarga & $8.221 .250,00$ & $2.577 .194,36$ & $4.951 .733,34$ & $1.557 .148,85$ \\
\hline Jumlah & $11.660 .681,82$ & $3.655 .386,15$ & $8.349 .866,67$ & $2.625 .744,24$ \\
\hline
\end{tabular}

Sumber : Data diolah pada 2011

Berdasarkan Tabel 6, dapat diketahui bahwa rata-rata biaya yang dikeluarkan untuk penyusutan peralatan di Desa Tunggang adalah sebesar Rp 1.068.806,11 per usahatani atau sebesar Rp 335.048,94 per hektar dan pada Desa Padang Gading biaya untuk penyusutan alat besar Rp. 950.982,00 per petani atau sebesar Rp. 299.050,94 per hektar.

\section{Biaya Tetap ( Fixed Cost)}

\section{Penggunaan dan Biaya Penyusutan Peralatan}

Alat-alat pertanian yang digunakan oleh petani dalam suatu kegiatan usahatani umumnya tidak habis dipakai dalam satu kali musim tanam, untuk itu perlu dihitung biaya penyusutannya. Jenis peralatan yang digunakan antara lain: Dodos, Gerek, Gancu, Gerobak dan alat semprot. Perhitungan nilai penyusutan adalah harga awal dikurang harga akhir dibagi umur ekonomis, dalam perhitungan tersebut harga akhir diasumsikan bernilai nol. Untuk lebih jelasnya biaya penyusutan alat pada Desa Tunggang dan Desa Padang Gading dapat dilihat pada Tabel 7. 
Tabel 7. Rata-Rata Jumlah Biaya Penyusutan Peralatan Dalam Usahatani Kelapa Sawit di Desa Tunggang dan Desa Padang Gading.

\begin{tabular}{|c|c|c|c|c|}
\hline \multirow{2}{*}{ Jenis } & \multicolumn{2}{|c|}{ Tungggang } & \multicolumn{2}{|c|}{ Padang Gading } \\
\hline & $(\mathrm{Rp} / \mathrm{Ut})$ & $(\mathrm{Rp} / \mathrm{Ha})$ & $(\mathrm{Rp} / \mathrm{Ut})$ & $(\mathrm{Rp} / \mathrm{Ha})$ \\
\hline Dodos & $101.458,33$ & $31.805,12$ & $91.000,00$ & $28.616,35$ \\
\hline Gerek & $408.068,18$ & $127.921,06$ & $423.000,00$ & $133.018,87$ \\
\hline Gancu & $32.395,83$ & $10.155,43$ & $13.680,00$ & $4.301,89$ \\
\hline Gerobak & $427.982,95$ & $134.163,93$ & $318.400,00$ & $100.125,79$ \\
\hline Alat Semprot & $98.900,81$ & $31.003,39$ & $104.902,00$ & $32.988,05$ \\
\hline Jumlah & $1.068 .806,11$ & $335.048,94$ & 950.982 .00 & $299.050,94$ \\
\hline
\end{tabular}

Sumber : Data diolah pada 2011

\section{Biaya Pajak Lahan}

Lahan merupakan faktor produksi yang sangat penting dalam proses produksi usahatani. Lahan yang digunakan oleh petani dalam kegiatan usahatani kelapa sawit adalah lahan milik sendiri. Oleh karena itu lahan yang ada dikenakan sejumlah pajak. Besarnya biaya pajak lahan yang dikeluarkan tergantung pada luas lahan. Rata-rata besarnya biaya pajak lahan yang dikeluarkan oleh petani dalam usahatani kelapa sawit Desa Tungggang adalah sebesar adalah sebesar Rp. 134.613,64 perluas usahatani atau sebesar Rp 42.204,28 per hektar pada Desa Padang Gading pajak lahan sebesar Rp.197.240,00 perluas usahatani atau sebesar Rp. 62.025,16 per hektar.

\section{Total Biaya Usahatani Kelapa Sawit}

Rincian biaya-biaya yang dikeluarkan oleh petani Desa Tunggang dan Desa Padang Gading disajikan pada Tabel 8.

Tabel 8. Rata-rata Biaya Produksi Usahatani Kelapa Sawit Desa Tunggang dan Desa Padang Gading

\begin{tabular}{lrrrr}
\hline & \multicolumn{2}{c}{ Tunggang } & \multicolumn{2}{c}{ Padang Gading } \\
\cline { 2 - 5 } Biaya Produksi & $(\mathrm{RP} / \mathrm{Ut})$ & $(\mathrm{Rp} / \mathrm{Ha})$ & $(\mathrm{Rp} / \mathrm{Ut})$ & $(\mathrm{Rp} / \mathrm{Ha})$ \\
\hline Biaya Tidak tetap & & & & \\
A.Pupuk & $1.595 .954,55$ & $500.299,23$ & - & - \\
$-\quad$ Urea & $2.592 .681,82$ & $812.752,92$ & - & - \\
$-\quad$ KCL & $2.106 .681,82$ & $660.401,82$ & - & - \\
$-\quad$ TSP & - & - & $1.057 .800,00$ & $332.641,51$ \\
- SP36 & - & - & $1.593 .400,00$ & $501.069,18$ \\
- Poska & $780.306,82$ & $244.610,29$ & $552.400,00$ & $173.710,69$ \\
B.Pestisida & & & & \\
C. Biaya Tenaga Keja & & & & \\
-TK Dalam Keluarga & $3.439 .431,82$ & $1.078 .191,79$ & $3.398 .133,33$ & $1.068 .595,39$ \\
-TK Luar Keluarga & $8.221 .250,00$ & $2.577 .194,36$ & $4.951 .733,34$ & $1.557 .148,85$ \\
Biaya Tetap & & & &
\end{tabular}

108 | Een Supriadi, Musriyadi Nabiu, Septri Widiono. Dampak Pendirian ... 


\begin{tabular}{lrrrr} 
A. Penyusutan Alat & $1.068 .806,11$ & $335.048,94$ & $950.982,00$ & $299.050,94$ \\
B. Pajak Lahan & $134.613,64$ & 42.204 .28 & $197.240,00$ & $62.025,16$ \\
\hline Biaya Total & $19.939 .726,57$ & $6.250 .697,98$ & $12.701 .688,67$ & $3.994 .241,72$ \\
\hline
\end{tabular}

Sumber : Data Diolah Pada 2011

Dari Tabel 8 dapat dilihat bahwa total biaya yang dikeluarkan oleh petani kelapa sawit Pada Desa Tunggang adalah sebesar Rp. 19.939.726,58 per usahatani atau sebesar Rp. 6.250.697,98 per hektar di Desa Padang Gading total biaya yang dikeluarkan adalah sebesar Rp. 12.701.688,67 per usahatani atau sebesar Rp. 3.994.241,72 perhektar. Jika dilihat antara Desa Tunggang dan Desa Padang Gading total biaya Desa Tunggang lebih besar hal ini di karenakan semakin itensif perawatan dan makin meningkatnya produksi makin besar biaya yang akan dikeluarkan petani kelapa sawit.

\section{Produksi Usahatani Kelapa Sawit}

Produksi kelapa sawit diukur dalam penelitian ini adalah produksi kelapa sawit dalam satu tahun dalam satuan kilogram. Dari Tabel 8, menunjukkan bahwa rata-rata produksi usahatani kelapa sawit desa Tunggang sebesar $87.185,00$ per usahatani atau 27.330,72 per hektar dengan rata-rata luas lahan 3,19 hektar. Di Desa Padang Gading rata-rata produksi kelapa sawit dalam satu tahun adalah sebesar 57.265,60 per usahatani atau sebesar 18.008,05 per hektar dengan rata-rata luas lahan 3,18 hektar. Tabel 10, menunjukkan bahwa produksi kelapa sawit yang berada disekitar PT. Bumi Mentari Karya di Desa Tunggang yang penduduknya melakukan mitra kerjasama lebih produktif dibandingkan sebelum melakukan mitra kerjasama. Desa yang tidak melakukan mitra digambarkan dengan Desa Padang Gading. Produksi rata-rata dalam satu hektar per bulan di Desa Tunggang yaitu sebesar 2,277,56 $\mathrm{Kg} / \mathrm{Ha} /$ Bulan hal ini lebih produktif dari Desa Padang Gading yaitu sebesar $1.500,67 \mathrm{Kg} / \mathrm{Ha} /$ Bulan. Menurut pendapat (Wiranta, 1997) dalam Rachman dan Subroto (2002) mengatakan bahwa hasil produktifitas kelapa sawit yang baik antara 2,2 ton -4 ton dalam satu bulan.

Tabel 9. Rata-rata Produksi Usahatani kelapa sawit Desa Tunggang dan desa Padang Gading

\begin{tabular}{lrrrr}
\hline \multirow{2}{*}{ Uraian } & \multicolumn{2}{c}{ Tunggang } & \multicolumn{2}{c}{ Padang Gading } \\
\cline { 2 - 5 } & $(\mathrm{Kg} / \mathrm{Ut})$ & $(\mathrm{Kg} / \mathrm{Ha})$ & $(\mathrm{Kg} / \mathrm{Ut})$ & $(\mathrm{Kg} / \mathrm{Ha})$ \\
\hline Produksi(Kg/Th) & $87.185,00$ & $27.330,72$ & $57.265,60$ & $18.008,05$ \\
Produksi (Bln) & $7.265,42$ & $2.277,56$ & $4.772,13$ & $1.500,67$ \\
\hline
\end{tabular}

Sumber : Data diolah pada 2011

\section{Penerimaan dan Pendapatan Usahatani Kelapa Sawit}

Penerimaan dalam penelitian ini dihitung dengan cara jumlah produksi dalam satu tahun dikali dengan harga jual. Faktor yang mempengaruhi 
penerimaan adalah harga jual, dalam hal ini harga jual yang digunakan adalah harga jual rata-rata pertahun. Rata-rata harga jual kelapa sawit di Desa Tunggang pada saat penelitian adalah Rp. 1200/kg dan rata-rata harga jual kelapa sawit di Desa Padang Gading adalah Rp. 1100/Kg.

Tabel 10. Rata-rata Penerimaan, Pendapatan Usahatani kelapa sawit Desa Tunggang dan Desa Padang Gading

\begin{tabular}{crrrr}
\hline \multirow{2}{*}{ Uraian } & \multicolumn{2}{c}{ Tunggang } & \multicolumn{2}{c}{ Padang Gading } \\
\cline { 2 - 5 } & \multicolumn{1}{c}{$(\mathrm{Rp} / \mathrm{Ut})$} & \multicolumn{1}{c}{$(\mathrm{Rp} / \mathrm{Ha})$} & \multicolumn{1}{c}{$\mathrm{Rp} / \mathrm{Ut})$} & \multicolumn{1}{c}{$\mathrm{Rp} / \mathrm{Ha})$} \\
\hline Penerimaan(Rp/Th) & $104.622 .000,00$ & $32.796 .865,20$ & $62.992 .160,00$ & $19.808 .855,35$ \\
Total Biaya(Rp/Th) & $19.939 .726,57$ & $6.250 .697,98$ & $12.701 .688,67$ & $3.994 .241,72$ \\
\hline Pendapatan(Rp/Th) & $84.682 .273,43$ & $26.546167,22$ & $50.290 .471,33$ & $15.814 .613,63$ \\
\hline
\end{tabular}

Sumber : Data diolah pada 2011

Tabel 10, menunjukkan Penerimaan yang diterima petani di Desa Tunggang sebagai lokasi perusahaan PT. Bumi Mentari Karya adalah Rp. 104.622.000,00 per usahatani atau Rp. 32.796.865,20 per hektar dan penerimaan petani Desa Padang Gading adalah Rp. 62.992.160,00 per usahatani atau Rp. 19.808.855,35 per hektar. Penerimaan petani kelapa sawit Desa Tunggang lebih besar dari pada Desa Padang Gading, artinya bahwa pendapatan petani setelah melakukan kemitraan dengan perusahaan lebih besar dari nonmitra Penyebab dari perbedaan ini adalah Desa Tunggang disekitar perusahaan melakukan mitra kerjasama dalam bimbingan teknsis budidaya kelapa sawit, kerjasama dalam hal jual beli, dan ada manajemen dari desa dan perusahaan yang mengelola usahatani kelapa sawit.

Tabel 10, menunjukkan bahwa pendapatan rata-rata yang di peroleh petani Desa Tunggang yaitu sebesar Rp $84.682 .273,43$ per petani atau Rp $26.546167,22$ perhektar dan rata-rata pendapatan yang diperoleh petani kelapa sawit Desa Padang Gading yaitu sebesar Rp 50.290.471,33 per petani atau sebesar Rp. 15.814.613,63per hektar. Dengan luas lahan yang relaif homogen dan umur tanaman sudah masuk usia produktif diperoleh hasil bahwa rata-rata pendapatan usahatani Desa Tunggang lebih besar setelah adanya perusahaan dibanding sebelumnya adanya perusahaan. Hal ini dipengaruhi oleh produksi dan total biaya produksi. Dengan hal ini dapat disimpulkan keberadaan perusahaan memberi pengaruh pada peningkatan pendapatan atau dengan kata lain Keberadaan PT. Bumi mentari karya memberi dampak positif pada peningkatan pendapatan usahatani kelapa sawit desa Tunggang.

Hasil analisis terhadap uji beda rata-rata pendapatan usahatani kelapa sawit Desa Tunggang dan Desa Padang Gading didapat Nilai t hitung : 3,9302 angka tersebut lebih besar dari nilai $t$ tabel 1,99601 di taraf kepercayaan $95 \%$, jadi $\mathrm{t}$ hitung $>\mathrm{t}$ tabel maka keputusannya : Terima $\mathrm{H}_{\mathrm{a}}$ atau tolak $\mathrm{H}_{0}$. Artinya, pendapatan usahatani kelapa sawit Desa Tunggang lebih besar setelah adanya PT Bumi Mentari Karya artinya secara statistik hasil penelitian ini menunjukkan keberadaan industri kelapa sawit PT. Bumi Mentari Karya memberi dampak positif bagi pendapatan usahatani kelapa sawit Desa Tunggang. Peningkatan 
pendapatan ini dipengaruhi oleh hasil produktivitas Desa Tunggang lebih besar dibandingakan sebelum keberadaan PT.Bumi Mentari Karya hal ini dipengaruhi perbedaan perlakuan dalam teknik budidaya mulai dari jenis pupuk, perlakuan dosis pupuk, tatacara pemupukan, harga jual, dan akses jalan kebun yang lebih baik.

\section{SIMPULAN DAN SARAN}

\section{Simpulan}

1. Keberadaan PT.Bumi Mentari Karya memberi pengaruh terhadap peningkatan hasil produksi usahatani kelapa sawit masyarakat Desa Tunggang yaitu $87.185,00 / \mathrm{kg}$ perusahatani atau $27.330,72 / \mathrm{kg}$ perhektar dibandingkan hasil produksi usahatani kelapa sawit Desa Padang Gading yaitu 57.265,60 / kg perushatani atau 18.008,05 kg perhektar. Produktifitas kelapa sawit disekitar perusahaan PT. Bumi Mentari Karya yang bermitra dengan perusahaan lebih Tinggi dibandingkan sebelum melakukan mitra ini di tunjukkan dengan peningkatan produktivitas usahatani kelapa sawit Desa Tunggang .

2. Pendapatan rata-rata yang diterima oleh petani Desa Tunggang yaitu sebesar Rp. 84.682.273,43 per petani atau Rp. 26.546167,22 perhektar ini lebih besar bila dibandingkan usahatani kelapa sawit desa Padang Gading sebesar 50.290.471,33 per petani atau Rp. 15.814.613,63 perhektar Dengan Nilai t hitung : 3,9302 angka tersebut lebih besar dari nilai $t$ tabel 1,99601 di taraf kepercayaan $95 \%$, jadi $\mathrm{t}$ hitung $>\mathrm{t}$ tabel maka keputusannya : Terima $\mathrm{H}_{\mathrm{a}}$ atau tolah $\mathrm{H}_{0}$ artinya pendapatan usahatani kelapa sawit Desa Tunggang lebih besar setelah adanya PT Bumi Mentari Karya artinya secara statistik Hasil penelitian ini menunjukkan Keberadaan industri kelapa sawit PT. Bumi Mentari Karya memberi dampak positif bagi pendapatan usahatani kelapa sawit Desa Tunggang.

\section{Saran}

Dari kesimpulan terlihat adanya peningkatan pendapatan pada Perkebunan kelapa sawit masyarakat sekitar PT. Bumi Mentari Karya di Desa Tunggang hal ini menunjukkan dampak positif keberadaan perusahaan bagi usaha kelapa sawit masyarakat Desa Tunggang maka sekiranya perlu kajian pada pengembangan usaha perkebunan masyarakat pada desa lain agar produksi dan pendapatan masyarakat desa lain lebih baik. 


\section{DAFTAR PUSTAKA}

Doni, Novian. 2008. Analisis Fungsi Keuntungan dan Pemasaran Usahatani Jagung di Kabupaten Seluma Propinsi Bengkulu. Skripsi Jurusan SOSEK Faperta UNIB (tidak dipublikasikan).

Djarwanto dan Pangestu, Subagyo.1993. Statistik Induktif. BPFE. Yogyakarta

Helvina, Febriandini. 2011. Kajian Kemitraan Pada PT. Agrowiyana Kabupaten Tanjung Barat Provinsi Jambi. Skripsi. Fakultas Ekonomi dan Manajemen. IPB Bogor,Jawa Barat.

Mubyarto, 1989. Pengantar Ekonomi Pertaniaan. LP3S. Jakarta

Nazir, M. 1988. Metode Penelitian. Ghalia. Jakarta

Nahriyanti. 2008. Analisis Efisiensi Penggunaan Faktor-Faktor Produksi Pada Usahatani Jagung (Studi kasus Petani Jagung di Kel. Penreg Kec. Baranti Kab. Sidrap). http://www.indoskripsi.com.

Permatasari, Ratna. 2008. Prospek Pengembangan Perkebunan Kelapa Sawit Rakyat (Studi Kasus KUD-P3RSU Desa Aek Nabara, Bilah Hulu Kabupaten Labuhan Batu). Skripsi. Fakultas Pertanian, USU, Medan.

Rachman, Anas dan Subroto, Bubun. 2002. Kebijaksanaan dan Strategi Pengembangan Agroindustri Kelapa Sawit di Indonesia. Jurnal Forum Penelitian Agroekonomi, 11(1):39-55.

Saputra, Dani, 2010. Analisa Produksi dan yang dialokasikan ke pasar oleh nelayan di pulau kecil terluar. Skripsi. Jurusan Sosial Ekonomi Pertanian, Universitas Bengkulu (tidak dipublikasikan).

Soekartawi.1999. Analisa Usahatani. UI-Press, Jakarta

Togatorop, Donda. 2005. Evaluasi Konsistensi Mutu Bahan Baku dan Rendemen Serta Mutu CPO Yang dihasilkan pada PMKS PT. Agricinal. Skripsi. Jurusan Teknologi Industri Pertanian Universitas Bengkulu. Bengkulu

Zakir, Fidrizal. 1990. Pengembangan Usaha Perkebunan Kelapa Sawit Serta Evaluasi Pendapatan di Proyek Nes I1 ADB Sungai Galuh PT. Perkebunan Bunanan $V$, Propinsi Riau. Fakultas Pertanian, IPB, Bogor, Jawa Barat. 